comparing PTCA and stenting with bypass surgery will ultimately prove helpful in clinical decision making. However, one should not forget that, particularly when considering the difficult issue of whether to select a patient for intervention or surgery, surgery itself is going to go through a rapid evolution in the coming years in relation to more minimally invasive techniques. By the time we finally get a good answer as to whether PTCA with stenting is completely equivalent to coronary bypass grafting, the whole stage may have moved in that arena as well.

It is clear that interventional cardiology is going to grow at at least the current rate for some years to come. This is not withstanding the possible explosion that may occur in this specialty if direct intervention for myocardial infarction starts to become established in the UK in the way that it is being established in Europe and North America.

BCIS will continue its commitment to rigorous training and audit of intervention practice in the UK, and there is no doubt that for a while at least the stent will reign supreme within the coronary artery.

1 Black N, Langhan S, Coshall C, Parker J. Impact of the 1991 NHS reforms on the availability and use of coronary revascularisation in the UK (1987-1995). Heart 1996;76(suppl 4):1-32.

2 British Cardiac Society (BCS) and British Cardiovascular Intervention Society (BCIS) working group on interventional cardiology. Planning for coronary angioplasty: guidelines for training and continuing competence. Heart guidelines for trainin

\title{
Lesions I don't stent
}

Clive A Layton

Ten years have passed since the concept of stenting coronary arteries became a practical reality. ${ }^{1}$ During that time the technique has evolved with improvements in technology, stent design, the design of delivery systems, selection of suitable lesions and technique. Lastly there has been a change in the perceived need for anticoagulation. ${ }^{2}$

Contraindications have evolved in parallel with these developments. Whereas stenting for any indication other than an angioplasty disaster was exceptional, results of observational studies $^{3}$ and randomised trials ${ }^{4}$ have led to a reappraisal. Indications have broadened so that many units use stents in $50 \%$ or more of angioplasties. Conservative units with stenting rates of $20 \%$ or less find it increasingly difficult to justify their reluctance to stent.

Factors previously considered as contraindications to stenting, such as large branches, long lesions, lesions on sharp bends, and increased risk of anticoagulants are no longer considered to be so significant. Even the left main stem is no longer immune from stenting as a bailout procedure, even when not protected by one or more bypass grafts. Wire stents can be used on sharp bends or to cover large side-branches and in the left main stem. Longer stents allow a range of lengths to be covered. Greater awareness of the role of antiplatelet agents, including IIb/IIIa receptor inhibitors, has reduced the risk of subacute stent occlusion and haemorrhage. Lesions in vessels where the approach to the site of the stenosis is extremely tortuous continue to pre- sent a challenging problem but improvements in delivery system design and the use of stiffer wires to straighten the target vessel temporarily make these lesions more amenable, and the contraindication is now relative rather than absolute.

I define only two categories as absolutely unsuitable for stenting. First, lesions that cannot be predilated, identified by persistent indentation during predilatation at whatever pressure is applied. These lesions, if stented, continue to show indentation of the stent, which can be confirmed using intracoronary ultrasound, and the risk of subacute occlusion is high. It is important to distinguish these lesions from those in which the balloon indentation disappears during predilatation but angiography immediately afterwards shows the stenosis to remain because of recoil. These lesions will respond well to stenting. Second, lesions in vessels smaller than $2.5 \mathrm{~mm}$ diameter are not stented because of the incidence of thrombosis and restenosis.

1 Sigwart U, Puel J, Mirkovitch V, Joffre F, Kappenberger L. Intravascular stents to prevent occlusion and restenosis after transluminal angioplasty. $N$ Engl $f$ Med 1987;316: 701-6.

2 Schomig A, Neumann FJ, Kastrati A, Schuhlen H, Blasini $\mathrm{R}$, Hadamitzky $\mathrm{M}$, et al. A randomized comparison of antiplatelet and anticoagulant therapy after the placement of coronary artery stents. $N$ Engl $\mathcal{F}$ Med 1996;334: 1084-9.

3 Vaishnav S, Aziz S, Layton C. Clinical experience with the Wiktor stent in native coronary arteries and coronary bypass grafts. Br Heart $\mathcal{f}$ 1994;72:288-93.

4 Serruys PW, de Jaegere P, Kiemeneij F, Macaya C, Rutsch W, Heyndrickx G, et al. A comparison of balloonexpandable-stent implantation with balloon angioplasty in patients with coronary artery disease. $N \mathrm{Engl} \mathscr{f} \mathrm{Med}$ 1994;331:489-95. 